Dicle Tip Dergisi / Dicle Med J (2019) 46 (2) : 307 - 313

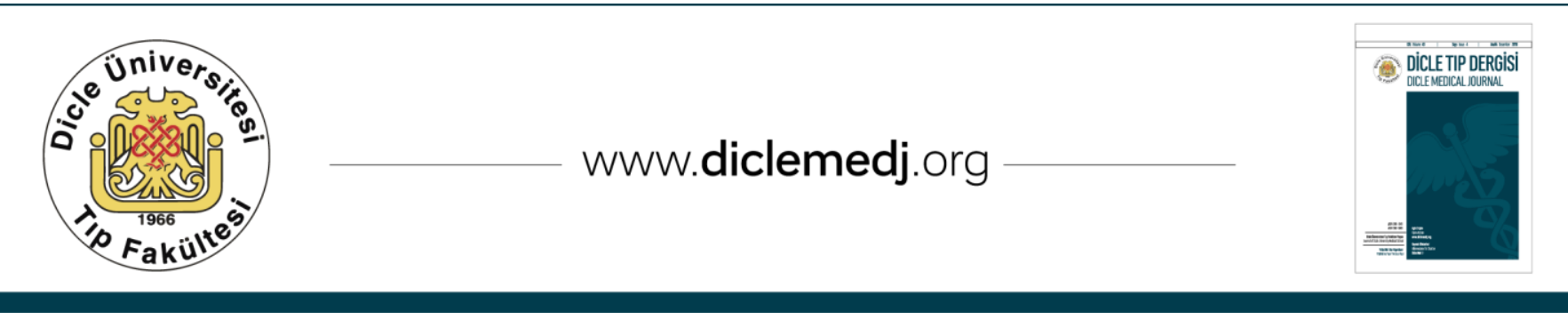

Özgün Araștırma / Original Article

\title{
Determination of ANAE and AcP-ase Positivity in the Peripheral Blood of Pregnant Women with Hypothyroidism
}

\author{
Fatma Çolakoğlu1 ${ }^{1}$ Hasan Hüseyin Dönmez², Fatma Kılıç³ \\ 1 Dept. of Nutrition and Dietetics, Faculty of Health Sciences, Karamanoglu Mehmetbey Univ, 70100, Karaman, Turkey ORCID: 0000-0003-0410-5523 \\ 2 Department of Histology and Embryology, Faculty of Veterinary Medicine, Selcuk University, 42075, Konya, Turkey ORCID: 0000-0003-4664-8489 \\ 3 Department of Obstetrics and Gynecology, Karaman State Hospital, 70100, Karaman, Turkey ORCID: 0000-0002-9735-3552
}

Received: 14.12.2018; Revised: 12.04.2019; Accepted: 03.05.2019

\begin{abstract}
Objective: Pregnancy is a stress factor for thyroid functions. The most commonly observed thyroid disorder is hypothyroidism. The immune system is affected both by pregnancy and hypothyroidism. This disorder causes a decrease in humoral and cell-mediated immune responses. This study was aimed at the comparison of alpha-naphthyl acetate esterase- and acid phosphatase-positive $\mathrm{T}$ lymphocyte distribution between healthy and hypothyroid pregnant women.

Methods: Blood samples were taken from healthy and hypothyroid pregnant women between June-December 2016. The sampled subjects included 10 healthy non-pregnant women (HC), 10 healthy pregnant women (HP), and 30 hypothyroid pregnant women in different trimesters of pregnancy (HpPTRI, HpPTRII and HpPTRIII). From each of these groups, six smears were prepared and histologically stained for ANAE and AcP-ase activity and with May Grünwald-Giemsa.

Results: The lowest ANAE- and AcP-ase-positive T lymphocyte percentages were detected in Group HP, and these percentages were higher in the hypothyroid pregnant groups, compared to Group HC $(\mathrm{P}<0.05)$. Based on PBL counts, the lowest lymphocyte and highest neutrophil leukocyte rates were detected in the pregnant groups. Hypothyroid pregnant women were determined to have monocytic leukocyte rates lower than those of Group HC and Group HP $(\mathrm{P}<0.05)$.

Conclusions: In this study, it was concluded that significant alterations had occurred in the PBL and ANAE- and AcPase-positive $\mathrm{T}$ lymphocyte counts of Group HP and the hypothyroid pregnant groups. These findings provide important data about the immunity of hypothyroid pregnant women.
\end{abstract}

Keywords: ANAE, AcP-ase, Hypothyroidism, Lymphocyte, Pregnancy.

DOI: $10.5798 /$ dicletip

Yazışma Adresi / Correspondence: Fatma Çolakoğlu, Department of Nutrition and Dietetics, Faculty of Health Sciences, Karamanoglu Mehmetbey University, 70100, Karaman, Turkey e-mail: fcolakoglu@kmu.edu.tr 


\section{Hipotiroidli Gebe Kadınların Periferik Kanında ANAE ve AcP-az Pozitivitesinin Belirlenmesi}

\section{Öz}

Amaç: Gebelik tiroid bezi fonksiyonları için bir stres faktörüdür. En sık görülen tiroid bozukluğu ise hipotiroidizmdir. Bağışıklık sistemi hem gebelikten hem de hipotiroidizmden etkilenmektedir. Bu bozukluk, humoral ve hücre aracılı immün cevaplarda azalmaya neden olmaktadır. Bu çalışma, sağlıklı gebeler ile hipotiroidli gebeler arasındaki alfa naftil asetat esteraz ve asit fosfataz pozitif T lenfosit dağılımlarını karşılaştırmayı amaçlamaktadır.

Yöntemler: 2016 Haziran-Aralık ayları arasında sağlıklı ve hipotiroidi olan gebelerden kan örnekleri alındı. Örneklemede 10 sağlıklı gebe olmayan kadın (SK), 10 sağlıklı gebe (SG) ve gebeliğin farklı trimesterlerindeki 30 hipotiroidi gebe (HpGTRI, HpGTRII ve HpGTRIII) kadının kan örnekleri vardı. Bu gruplardaki kişilerin her birinden ANAE ve AcP-az enzim aktivitesi ile May Grünwald-Giemsa için altı adet kan frotisi hazırlanarak histolojik olarak boyandl.

Bulgular: En düșük ANAE- ve AcP-az pozitif T lenfosit yüzdeleri sağlıklı gebe grubunda (Grup SG) belirlenirken; bu oranın hipotiroidli gebelerde (HpGTRI, HpGTRII ve HpGTRIII) sağlıklı gebe olmayanlardan (Grup SK) daha yüksek olduğu bulundu $(\mathrm{P}<0.05)$. İstatistiksel olarak, periferik kan lökosit $(\mathrm{PKL})$ sayımlarına göre, en düşük lenfosit ve en yüksek nötrofil lökosit oranları tüm gebe gruplarında tespit edildi. Hipotiroidi olan gebelerin sağlıklı gebe olmayan (Grup SK) ve sağlıklı gebe grubuna (Grup SG) göre daha düşük monosit oranına sahip olduğu gözlendi ( $\mathrm{P}<0.05)$.

Sonuç: Bu çalışmada, sağlıklı gebe (Grup SG) ve hipotiroid gebe gruplarının (HpGTRI, HpGTRII ve HpGTRIII) PKL ile ANAE- ve AcP-az pozitif T lenfosit sayılarında anlamlı değișikliklerin olduğu sonucuna varıldı. Bu bulgular hipotiroidi gebe kadınların bağışıklığı hakkında önemli veriler sağlamaktadır.

Anahtar kelimeler: ANAE, AcP-az, hipotiroidizm, lenfosit, gebelik.

\section{INTRODUCTION}

Pregnancy alters the rates and distribution of maternal immune system cells, in particular those of T lymphocytes, in the peripheral blood (PB) and endometrial tissue ${ }^{1}$. During pregnancy, the absolute counts of $\mathrm{T}$ and $\mathrm{B}$ lymphocytes significantly decrease ${ }^{2}$. Pregnancy is also known to be a stress factor for the thyroid gland ${ }^{3}$. The thyroid gland plays a major role in immunity and reproduction ${ }^{4}$.

Thyroid hormones have significant roles in conception and the maintenance of healthy pregnancy 5 . Hypothyroidism leads to decreased humoral and cell-mediated immune responses. Low concentrations of thyroid hormones can stimulate $\mathrm{T}$ cell proliferation ${ }^{6}$. In clinical cases of hypothyroidism, the spontaneous migration of polymorphonuclear leukocytes (PMNL) was found to be impaired ${ }^{7}$. Alterations that occur in the endocrine and immune systems during pregnancy bear importance for maternal and foetal health, and may affect the future intellect of the unborn child ${ }^{3}$.

In some mammalian species such as the Angora cat, alpha-naphthyl acetate esterase (ANAE), is known as a marker, used to distinguish mature T lymphocytes ${ }^{8}$. Acid phosphatase (AcP-ase), which is a lysosomal enzyme, is used as a marker for leukocytes, and particularly $\mathrm{T}$ lymphocytes, in several species, including the duck $^{9}$.

This study was aimed at the comparison of ANAE- and AcP-ase-positive $\mathrm{T}$ lymphocyte distribution between healthy and hypothyroid pregnant women, in view of the scarcity of studies in this domain.

\section{METHODS}

This study was ethically approved by the Ethics Committee for Non-Interventional Clinical Research of Selcuk University, Faculty of Medicine (Approval numbered 2016/110). PB 
samples were taken from patients, who were referred to the Department of Obstetrics and Gynaecology of Karaman State Hospital. Patients were hypothyroid primiparous women, who were diagnosed or treated by an endocrinologist. Others were not included in this study. The patients gave their informed consent to participate in the study.

Two-ml PB samples were collected into heparinized tubes from 10 healthy nonpregnant women (HC), 10 healthy pregnant women (HP) in different trimesters (mostly the 2nd and 3rd trimesters), and 30 hypothyroid pregnant women in different trimesters of pregnancy (HpPTRI, HpPTRII and HpPTRIII) (1st, 2nd and 3rd trimesters, $n=10$ ) as determined by a gynaecologist. Pregnant women were between the 5th-40th weeks of pregnancy. Six blood smears were prepared from each PB sample. These preparations were first stained for ANAE and AcP-ase activity12, and were later counterstained with $1 \%$ methyl green (Sigma, product code: M8884, Germany). PBL counts were made in the blood smears stained with May Grünwald-Giemsa (Sigma, product code: MG1L, Germany) ${ }^{10}$.

In the smears, which were stained for ANAE activity, dot-like reddish brown granules demonstrated the presence of ANAE positive lymphocytes/T lymphocytes (Figure 1: A). In the smears, which were stained for AcP-ase activity, PBL containing 1-3 reddish granules were considered to be AcP-ase positive (Figure 1: B). For ANAE and AcP-ase activity, positivity was reported as the percentage of 200 lymphocytes counted under a light microscope, using a 100x objective lens and immersion oil. In the PBL counts, 100 leukocytes were counted under a light microscope, using a 40x objective lens, and the leukocyte formula was determined (Figure 1: C).

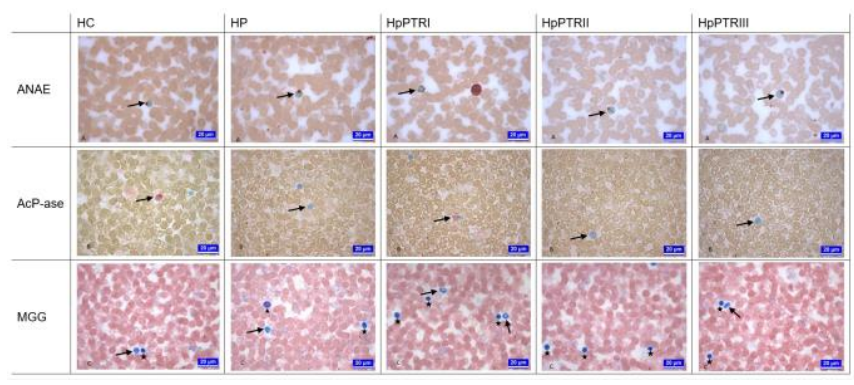

Figure 1. Images of $P B$ smear from the groups. A: ANAEpositive $\mathrm{T}$ lymphocytes. Demonstration of ANAE activity. Arrow: ANAE- positive T lymphocyte. B: An AcP-ase positive T lymphocytes. Demonstration of AcP-ase activity. Arrow: ACPase positive T lymphocyte. C: May Grünwald-Giemsa staining. Arrow: Neutrophil leukocyte. Arrowhead: Eosinophil leukocyte. Star: Lymphocyte. Bar: $20 \mu \mathrm{m}$.

\section{Statistics}

For the statistical evaluation of the results, the Kruskal-Wallis $\mathrm{H}$ test was conducted using the Statistical Package software (SPSS 2018). Statistical significance was set at $\mathrm{P}<0.05$.

\section{RESULTS}

The PBL percentages and ANAE- and AcP-ase positive $\mathrm{T}$ lymphocyte rates determined by enzyme histochemical staining are presented in Table 1. According to the data obtained for ANAE- and AcP-ase T lymphocyte positivity, the lowest ANAE- and AcP-ase positive $T$ lymphocyte (Figure 1: $\mathrm{A}$ and $\mathrm{B}$ ) rates were detected in Group HP, and these rates were higher in the hypothyroid pregnant groups, compared to Group HC $(\mathrm{P}<0.05)$. Statistically, according to the PBL counts, the lowest lymphocyte and highest neutrophil leukocyte rates were detected in the pregnant groups (Figure 1: C). 
Table 1: ANAE- and AcP-ase positive T lymphocyte rates, and PBL percentages in PB

\begin{tabular}{|c|c|c|c|c|}
\hline & Group $(n=10)$ & Mean rank & $\mathrm{Z}$ & $\mathrm{P}$ \\
\hline \multirow{5}{*}{$\begin{array}{l}\text { ANAE- positive } \\
\text { T lymphocyte }\end{array}$} & $\mathrm{HC}$ & 24.40 & \multirow{5}{*}{-1.931} & \multirow{5}{*}{0.00} \\
\hline & HP & 5.50 & & \\
\hline & HpPTRI & 31.80 & & \\
\hline & HpPTRII & 38.00 & & \\
\hline & HpPTRIII & 27.80 & & \\
\hline \multirow{5}{*}{$\begin{array}{l}\text { AcP-ase positive } \mathrm{T} \\
\text { lymphocyte }\end{array}$} & $\mathrm{HC}$ & 18.70 & \multirow{5}{*}{-2.578} & \multirow{5}{*}{0.00} \\
\hline & HP & 5.80 & & \\
\hline & HpPTRI & 27.75 & & \\
\hline & HpPTRII & 32.10 & & \\
\hline & HpPTRIII & 43.15 & & \\
\hline \multirow{5}{*}{ Neutrophil } & $\mathrm{HC}$ & 6.50 & \multirow{5}{*}{-0.835} & \multirow{5}{*}{0.00} \\
\hline & $\mathrm{HP}$ & 27.60 & & \\
\hline & HpPTRI & 34.85 & & \\
\hline & \begin{tabular}{|l|} 
HpPTRII \\
\end{tabular} & 32.00 & & \\
\hline & HpPTRIII & 26.55 & & \\
\hline \multirow{5}{*}{ Lymphocyte } & $\mathrm{HC}$ & 44.25 & \multirow{5}{*}{-0.871} & \multirow{5}{*}{0.00} \\
\hline & $\mathrm{HP}$ & 20.80 & & \\
\hline & HpPTRI & 17.00 & & \\
\hline & HpPTRII & 19.60 & & \\
\hline & HpPTRIII & 25.85 & & \\
\hline \multirow{5}{*}{ Monocyte } & $\mathrm{HC}$ & 34.55 & \multirow{5}{*}{-0.175} & \multirow{5}{*}{0.04} \\
\hline & HP & 30.50 & & \\
\hline & HpPTRI & 19.85 & & \\
\hline & HpPTRII & 21.90 & & \\
\hline & HpPTRIII & 20.70 & & \\
\hline \multirow{5}{*}{ Eosinophil } & $\mathrm{HC}$ & 31.80 & \multirow{5}{*}{-0.611} & \multirow{5}{*}{0.36} \\
\hline & HP & 27.90 & & \\
\hline & HpPTRI & 20.75 & & \\
\hline & HpPTRII & 25.35 & & \\
\hline & HpPTRIII & 21.70 & & \\
\hline \multirow{5}{*}{ Basophil } & $\mathrm{HC}$ & 26.50 & \multirow{5}{*}{0.00} & \multirow{5}{*}{0.72} \\
\hline & HP & 26.50 & & \\
\hline & HpPTRI & 26.50 & & \\
\hline & \begin{tabular}{|l} 
HpPTRII \\
\end{tabular} & 24.00 & & \\
\hline & HpPTRIII & 24.00 & & \\
\hline
\end{tabular}

HC: Healthy non-pregnant women, HP: Healthy pregnant women, HpPTRI: Hypothyroid pregnant women in the first trimester, HpPTRII: Hypothyroid pregnant women in the second trimester, HpPTRIII: Hypothyroid pregnant women in the third trimester. $\mathrm{P}<0.05$.

It was observed that hypothyroid pregnant women had monocytic leukocyte rates lower than those of Group HC and Group HP $(\mathrm{P}<0.05)$. No statistically significant difference was observed for the other leukocytes $(\mathrm{P}>0.05)$.

\section{DISCUSSION}

Severe hypothyroidism during pregnancy leads to spontaneous abortion, premature birth ${ }^{4}$, or impaired foetal neurocognitive development ${ }^{11}$. Furthermore, hypothyroidism gives rise to a decrease in both humoral and cellular immune responses. At the beginning of implantation, the embryo causes short-term inflammation for placental development. These processes affect the percentages of some PB cells. The most important alterations are observed in the percentages of the lymphocyte subpopulations ${ }^{12}$.

The ANAE enzyme is specific to $T$ lymphocytes ${ }^{8,9}$. Akbulut et all. ${ }^{13}$ observed that the $\mathrm{T}$ lymphocyte rate was suppressed throughout pregnancy and declined to $58-60 \%$. $\mathrm{T}$ lymphocytes are suppressed as of early pregnancy for the survival of the embryo. In this study, the highest ANAE- positive T lymphocyte rates were determined in the hypothyroid pregnant women, whilst the lowest ANAE- positive T lymphocyte rate was detected in Group HP. AcP-ase is another enzyme used for lymphocyte histochemistry. In previous research, it has been reported that the rate of AcP-ase positive lymphocytes decline during pregnancy ${ }^{14}$. In the present study, while the lowest AcP-ase positive lymphocyte rate was detected in Group HP, the other three groups of hypothyroid pregnant women were determined to have AcP-ase positive lymphocyte rates higher than those of Groups HC and HP. To date, no correlation has been reported between AcP-ase positive lymphocyte rates and pregnancy. As these lymphocytes are considered to be T lymphocytes in mammals, in previous research, AcP-ase histochemistry results may have been interpreted as ANAE results.

Previous studies that have investigated the effects of pregnancy on PB cells have mostly focussed on lymphocytes. Pisek et all. ${ }^{15}$ observed significant reductions in PBL counts 
during pregnancy, and indicated that this decline was due to reduced neutrophil leukocyte and lymphocyte counts. Akbulut et all. ${ }^{13}$ determined the lowest percentage of PB lymphocytes in the last trimester of pregnancy. In the present study, it was observed that the pregnant groups had the highest numbers of neutrophil leukocytes and the lowest lymphocyte rates. Statistical analysis revealed that the lowest monocyte rate belonged to the hypothyroid pregnant women.

The decrease in the ANAE- and AcP-ase positive $\mathrm{T}$ lymphocyte rates was attributed to progesterone, which is known as the pregnancy hormone. Progesterone has a specific role in promoting maternal-foetal tolerance, and shows an immunosuppressive effect in early pregnancy by suppressing the proliferation of lymphocytes through an increased number of progesterone receptors on these cells ${ }^{16}$. Cortisol, which is the hormone that initiates delivery, also has a suppressive effect on lymphocytes ${ }^{17}$. In view of this effect, it is suggested that the reason of the decline observed in the PB lymphocyte and AcP-ase positive lymphocyte rates could be an increased level of foetal cortisol in late pregnancy ${ }^{18}$. This would consequently reduce the rates of ANAE- and AcP-ase positive T lymphocytes in $\mathrm{PB}$.

The molecular mechanisms that regulate female reproduction involve the T3- hormoneinduced modulation of hormonal status 4 . During pregnancy, increased oestrogen levels stimulate the expression of thyroxine-binding globulin (TBG) in the liver. The increase observed in TBG expression is associated with an increase in the serum concentrations of total T3 and thyroxine (T4) ${ }^{19}$. Furthermore, free thyroid hormone levels usually increase with the release of human chorionic gonadotropin (hCG) from the placenta in the first trimester of pregnancy ${ }^{20}$. Under the thyrotropic effect of hCG, the level of thyroid-stimulating hormone (TSH) decreases during pregnancy 3 .
Endocrine organs are indirectly regulated by the immune system with several cytokines involved ${ }^{21}$. The thyroid gland, which is an endocrine gland, influences specific immune responsiveness. The proliferation and activation of $\mathrm{T}$ cells and $\mathrm{T}$ cell subtypes are stimulated in hypothyroid patients, who are characterized by low T3 and T4 levels ${ }^{6}$. It is known that ANAE- and AcP-ase positive lymphocytes are $\mathrm{T}$ lymphocytes in mammals ${ }^{13}$. The results of the present study demonstrated that the ANAE- and AcP-ase positive $\mathrm{T}$ lymphocyte rates of hypothyroid pregnant women were higher than those of the other groups.

It is known that thyroid hormones stimulate certain functions of PMNL. De Vito et all. ${ }^{6}$ reported that thyroid hormones could act in contradiction to some proinflammatory mechanisms, which involve monocytes and macrophages. In the present study, it was observed that hypothyroid pregnant women had monocyte rates lower than those of Group HP and Group HC. This was attributed to hormonal differences. Several findings suggest that thyroid hormones modify lymphocyte activity. Statistical analysis demonstrated that hypothyroid pregnant women had lymphocyte rates significantly higher than those detected in Group HP and Group HC. Neutrophil leukocytes, which are a subpopulation of PMNL, are the phagocytic cells that first reach the inflammation site ${ }^{22}$. The neutrophil leukocyte levels of Groups HpPTRI and HpPTRII being higher than those detected in Group HP was attributed to this migratory feature of neutrophil leukocytes.

\section{CONCLUSION}

In the present study, it was concluded that significant alterations had occurred in both ANAE- and AcP-ase positive T lymphocyte rates and PBL counts during pregnancy. Especially, the ANAE- and AcP-ase positive T lymphocyte 
ratios of hypothyroid pregnant women were higher than those of healthy pregnant women.

The continuation of pregnancy depends on the maintenance of the delicate balance of the mother's immune system. Pregnancy is a period that strongly influences the thyroid gland and its functions. Thyroid gland disorders are important for the health of both the mother and the foetus during pregnancy. The regular control of thyroid gland functions and the administration of treatment when required, both before and throughout pregnancy, are essential to the maintenance of a healthy pregnancy. The prevention of infertility, recurrent spontaneous abortions, low birth weight, foetal death, and mental and developmental disorders is possible only with a clear understanding of the mechanisms of the system. In the present study, it was concluded that significant alterations had occurred in both ANAE- and AcP-ase positive T lymphocytes and PBL counts during pregnancy in hypothyroid pregnant women. These findings provide important data for the assessment of the immunity of hypothyroid pregnant women. As the determination of these counts involves simple, much cheaper, and less time-consuming techniques, we suggest that laboratory services should be available to women for the early diagnosis of gestational disorders such as unclarified infertility and spontaneous abortions.

Conflicts of interest: The authors have no conflict of interests to declare.

Financial Disclosure: Karamanoglu Mehmetbey University Scientific Research Projects (BAP) Coordinating Office, Project no: 01-M-16.

\section{REFERENCES}

1. Robertson SA, Petroff MG, Hunt JS. Knobil and Neill's Physiology of Reproduction, 3rd edn. Philadelphia, USA: Elsevier, 2017: 1835-74.
2. Orgul G, Soyak B, Portakal O, et all. Total blood lymphocyte count alteration during and after pregnancy. GORM. 2017; 23: 11-3.

3. Stagnaro-Green A, Abalovich M, Alexander E, et all. Guideliness of the American Thyroid Association fort he diagnosis and management of the thyroid disease during pregnancy and postpartum. Thyroid. 2011; 21: 1081-125.

4. Abdelsamad DM, Ke R, Kutteh WH. Reference Module in Biomedical Sciences, 2nd edn. Philadelphia, USA: Elsevier, 2018: 1-5.

5. Karaca N, Akpak YK. Thyroid disorders and fertility. IJRMS. 2015; 3: 1299-304.

6. De Vito P, Incerpi S, Pederson JZ, et all. Thyroid hormones as modulators of immune activities at the cellular level. Thyroid. 2011; 21: 879-90.

7. Van Der Spek AH, Fliers E, Boelen A. Thyroid hormone metabolism in innate immune cells. J Endocrinol. 2017; 232: R67-R81.

8. Bayraktaroğlu AG, Şimșek Ö, Kürüm A, et all. Determination of alpha-naphthyl acetate esterase (ANAE) activity in peripheral blood leukocytes of pregnant, adult, and kitten Angora cats. Turk J Vet Anim Sci. 2015; 39: 57-61.

9. Dönmez HH, Eken E, Beşoluk K, et all. The histological characteristics and localisation of ACP-ase and ANAE positive lymphocytes in the eosophageal tonsil of the duck (Anas platyrhynchos). Avian Biol Res. 2012; 5: 115.

10. Demir R, Yılmazer S, Öztürk $M$, et all. Histolojik Boyama Teknikleri Bașvuru Kitabı, 1. baskı, Ankara, Palme Yayıncillk, 2007: 267-9.

11. Sahay Kumar R, Nagesh Sri V. Hypothyroidism in pregnancy. IJEM. 2012; 16: 364-70.

12. Warning JC, McCracker SA, Morris JM. A balancing act: mechanisms by which the fetus avoids rejection by the maternal immune system. Reprod. 2011; 141: 715-24.

13. Akbulut B, Sur E, Okur DN. Determination of the AgNOR parameters, MN frequency ANAE and ACP-ase positivity of PBL in pregnants. Selçuk Tıp Derg. 2015; 31: 344-50.

14. Sur E, Aydın İ, Öznurlu Y, ve ark. Merinos ırkı sağlıklı gebe koyunların perifer kan lenfositlerinde alfa naftil asetat esteraz ve asit fosfataz aktivitelerinin belirlenmesi. Kafkas Univ Vet Fak Derg. 2013; 19: 4838.

15. Pisek L, Travnicek J, Salat J, et all. Changes in white blood cells in sheep blood during selenium supplementation. Vet Med. 2008; 53: 255-9.

16. Lissauer DM, Eldershaw SA, Inman CF, et all. Progesterone promotes maternal-fetal tolerance by reducing human maternal $\mathrm{T}$-cell polyfunctionality and inducing a spesific cytokine profile. Eur J Immunol. 2015; 45: 2858-72. 
17. Bilandzic N, Simic B, Terzic S, et all. The influence of levamisole on cortisol concentration and peripheral blood in artificially stressed pigs. Vet Arc. 2010; 80: 477-89.

18. Vianna $\mathrm{P}$, Bauer ME, Dornfeld D, et all. Distress conditions during pregnancy may lead to pre-eclampsia by increasing cortisol levels and altering lymphocyte sensivity to glucocorticoids. Med Hypotheses. 2011; 77: 188-91.

19. Stagnaro-Green A, Pearce E. Thyroid disorders in pregnancy. Nat Rev Endocrinol. 2012; 8: 650-8.
20. Korevaar TIM, Rijke de YB, Chaker L, et all. Stimulation of thyroid function by human chorionic gonadotropin during pregnancy: A risk factor for thyroid disease and a mechanism for known risk factors. Thyroid. 2017; 27: 440-50.

21. Rosol T, Walling BE. Immunopathology in Toxicology and Drug Development, 1st Edn. Switzerland: Springer Int Publishing AG, 2017: 649-94.

22. Gartner LP, Hiatt JL. Color Textbook of Histology, 3rd edn. Philadelphia, USA: Elsevier, 2007: 219-49. 